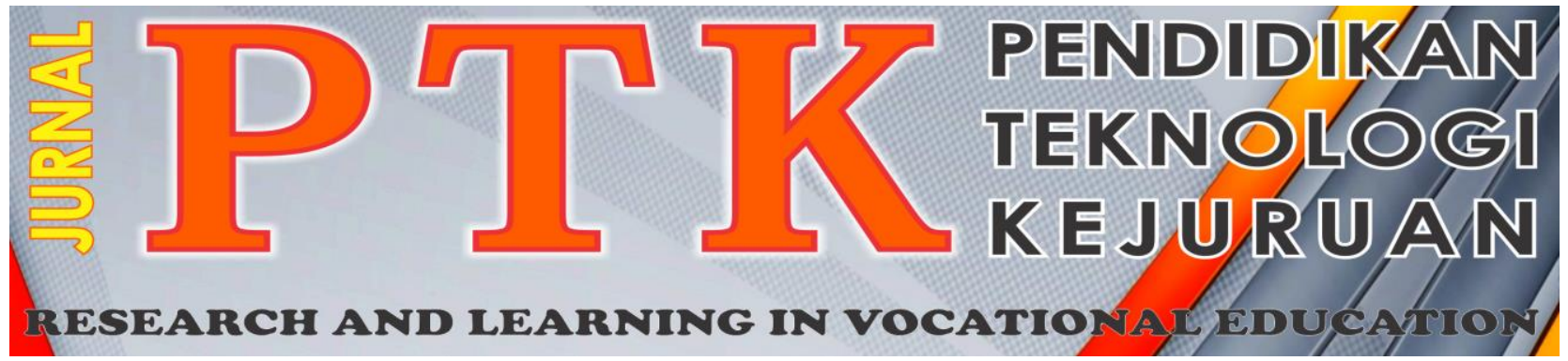

Vol. 2, No. 2, 2019

P-ISSN: 2621-3273

E-ISSN: 2621-1548

\title{
Hubungan Minat Belajar dengan Hasil Belajar dalam Mata Pelajaran SMAW di SMK Negeri 1 Sumatera Barat
}

\author{
Damrizal $^{1}$ dan Jasman ${ }^{2}$ \\ ${ }^{12}$ JurusanTeknik Mesin, Fakultas Teknik, Universitas Negeri Padang \\ ${ }^{*}$ Corresponding author, e-mail: damrizald6@ gmail.com ${ }^{1}$
}

\begin{abstract}
Abstrak - Permaslahan dalam penelitian ini adalah siswa kurang berminat dalam pembelajaran dan dilihat dari hasil ulangan harian yang didapatkan dari guru mata pelajaran SMAW bahwa hasil belajar mata pelajaran SMAW pada jurusan Teknik Pengelasan masih rendah. Adapun tujuan dari penelitian ini adalah untuk mengetahui ada tidaknya hubungan antara minat belajar dengan hasil belajar dalam mata pelajaran SMAW. Jenis penelitian ini adalah penelitian deskriptif korelasional. Sampel yang dinyatakan dalam penelitian ini adalah semua siswa kelas XI Jurusan Teknik Pengelasan yang mengikuti mata pelajaran Solid Metal Arc Welding yang berjumlah 48 orang. Hasil penelitian mengungkapkan adanya sumbangan hubungan positif antara minat belajar dengan hasil belajar siswa dalam bidang studi SMAW siswa Kelas XI Teknik Pengelasan SMK Negeri 1 Sumatera Barat Tahun pembelajaran 2018/2019. Hal ini memberikan arti semakin tinggi minat belajar maka hasil belajar SMAW semakin tinggi pula hasil belajarnya.
\end{abstract}

Kata kunci: Korelasional, Minat Belajar, Hasil Belajar, SMAW dan SMK Negeri 1 Sumatera Barat

Abstract-The problem in this study is that students are less interested in learning and seen from the daily results obtained from SMAW subject teachers that the learning outcomes of SMAW subjects in the Welding Engineering department are still low. The purpose of this study is to determine whether there is a relationship between interest in learning and learning outcomes in SMAW subjects. This type of research is descriptive correlational research. The sample stated in this study were all students of class XI of the Welding Engineering Department who participated in the 48 Solid Metal Arc Welding subjects. The results of the study revealed a contribution of a positive relationship between interest in learning with student learning outcomes in the field of study SMAW Class XI Welding Engineering students of SMK Negeri 1 West Sumatra 2018/2019 learning year. This gives the meaning of the higher interest in learning, the higher learning outcomes of SMAW learning outcomes.

Keywords: Correlation, Interest in Learning, Learning Outcomes, SMAW and SMK Negeri 1 West Sumatera

\section{Pendahuluan}

Minat belajar merupakan suatu keadaan di dalam diri siswa yang mampu mendorong dan mengarahkan perilaku mereka kepada pencapaian tujuan yang ingin dicapainya dalam mengikuti pendidikan di sekolah. (Pujadi, 56 : 2007). Dalam pencarian identitas diri diharapkan siswa dapat membentuk konsep dirinya yang positif karena akan berpengaruh terhadap pemikirannya, perilakunya, serta pendidikan dalam pencapaian hasil belajar. Tanpa adanya minat belajar yang tinggi, sebaik apapun fasilitas yang ada di sekolah, maka siswa tetap akan malas untuk belajar.

Minat belajar penting dalam proses pembelajaran karena tanpa adanya minat siswa maka pembelajaran tidak dapat diterima oleh siswa itu sendiri. Tidak ada minat dari seseorang siswa atau anak terhadap pelajaran akan timbul kesulitan belajar. Ada tidaknya minat terhadap sesuatu pelajaran dapat dilihat dari cara anak mengikuti pelajaran, lengkap tidaknya catatan, memperhatikan pelajaran atau tidak. Minat dalam sebuah pembelajaran pada dasarnya adalah penerimaan akan sesuatu hubungan antara diri sendiri dengan sesuatu di luar diri. Semakin dekat hubungan antara diri sendiri dengan sesuatu yang ada di luar diri semakin besar minatnya.

Siswa yang mempunyai minat belajar tinggi dalam proses pembelajaran dapat menunjang proses belajar mengajar untuk semakin baik, begitupun sebaliknya minat belajar siswa yang rendah maka kualitas pembelajaran akan menurun dan akan berpengaruh pada hasil belajar. Slameto (1995: 57) menerangkan minat adalah "Kecenderungan hati yang tinggi terhadap sesuatu". Minat merupakan 
sifat yang relatif menetap pada diri seseorang. Minat adalah ketertarikan atau kecenderungan yang tetap untuk memperhatikan atau terlibat terhadap sesuatu hal karena menyadari pentingnya atau bernilainya hal tersebut. Minat yang timbul dari diri siswa sendiri akan menimbulkan kemauan tanpa paksaan untuk memperjuangkan sesuatu yang diminatinya. Walgito Bimo (1981: 38) menyatakan minat adalah suatu keadaan di mana seseorang mempunyai perhatian terhadap obyek, yang disertai keinginan untuk mengetahui dan mempelajari maupun membuktikan lebih lanjut kecenderungannya untuk aktif terhadap objek tersebut. Minat belajar yang rendah mempengaruhi kemampuan anak didik dan secara tidak langsung berakibat pada rendahnya daya saing mereka dalam percaturan Internasional. Sekolah diharapkan akan dapat menghasilkan orangorang yang terampil dan bermoral. Untuk itu siswa sebagai anggota masyarakat sekolah harus dapat meningkatkan hasil belajarnya dengan menanamkan minat belajar sejak dini.

Peranan pendidikan sangat penting bagi kemajuan bangsa. Proses pendidikan tersebut dilaksanakan dalam wadah atau lembaga tertentu, seperti lembaga pendidikan formal dan non formal. Sekolah sebagai lembaga pendidikan formal harus turut serta mengemban tugas dalam mengembangkan ilmu dan teknologi yang bermamfaat bagi pembaharuan dibidang pendidikan dan bagi peningkatan kualitas manusia atau pembangunan manusia seutuhnya.

Salah satu cara untuk melihat tingkat keberhasilan siswa dalam hasil belajar adalah dengan melihat hasil belajar siswa di sekolah yaitu dengan melihat apakah dia telah dapat menguasai materi pelajaran tiap bidang studi yang dipelajarinya. Alat untuk melihat hasil belajar siswa di sekolah adalah dengan melihat laporan hasil belajarnya dan mid semester. Untuk meningkatkan prestasi siswa tersebut dituntut minat belajar yang tinggi, sehingga hasil belajar siswa yang diperoleh merupakan hasil dari apa yang diharapkan.

Pencapaian tujuan institusional SMK sesuai dengan fungsinya dalam rangka keseluruhan proses pendidikan pada khususnya adalah salah satu tugas sekolah sebagai lembaga pendidikan formal pada umumnya tidaklah mudah. Sepanjang tahun, khususnya pada tahun ajaran baru, mutu pendidikan yang berkaitan dengan pencapaian tujuan pendidikan secara umum disegala jenjang pendidikan formal, termasuk SMA sering dipermasalahkan. Permasalahan ini seringkali dikaitankan dengan adanya kecenderungan merosotnya minat belajar dan hasil belajar yang dicapai siswa.

Berdasarkan pengamatan yang penulis lakukan selama melaksanakan PPL di SMK Negeri 1
Sumatera Barat terlihat minat belajar siswa masih rendah. Kurangnya minat belajar siswa terlihat pada saat proses pembelajaran siswa tidak berani bertanya, siswa malas menulis apa yang sudah disampaikan oleh guru di depan kelas, siswa asyik bercerita dengan teman sebangkunya saat guru menerangkan materi pelajaran, siswa tidak berani mengemukakan pendapatnya saat di kelas, dan masalah yang sangat crusial adalah kebanyakan siswa yang sering berbicara sendiri dalam proses belajar mengajar yang sangat mengganggu keberlangsungan proses belajar mengajar, karena dapat mengganggu siswa yang lain yang ingin memperhatikan serta bagi siswa yang berbicara sendiri akan tidak dapat menyerap mat

\section{StUdi PUStaka}

\section{A. Minat Belajar}

Minat merupakan kecenderungan dalam diri individu untuk tertarik pada sesuatu objek atau menyenangi sesuatu objek. Menurut Witherington yang dikutip Suharsimi Arikunto (1983:100) "Minat adalah kesadaran seseorang terhadap suatu objek, suatu masalah atau situasi yang mengandung kaitan dengan dirinya.". Batasan ini lebih memperjelas pengertian minat tersebut dalam kaitannya dengan perhatian seseorang. Perhatian adalah pemilihan suatu perangsang dari sekian banyak perangsang yang dapat menimpa mekanisme penerimaan seseorang. Berdasarkan pengertian dimuka maka unsur minat adalah perhatian, rasa senang, harapan dan pengalaman.

Faktor-faktor yang menimbulkan minat dapat digolongkan sebagai berikut:

1. Faktor kebutuhan dari dalam. Kebutuhan ini dapat berupa kebutuhan yang berhubungan dengan jasmani dan kejiwaan.

2. Faktor motif sosial. Timbulnya minat dalam diri seseorang dapat didorong oleh motif sosial yaitu kebutuhan untuk mendapatkan pengakuan, perhargaan dari lingkungan dimana ia berada

3. Faktor emosional. Faktor ini merupakan ukuran intensitas seseorang dalam menaruh perhatian terhadap sesuat kegiatan atau objek tertentu

Berdasarkan pendapat di atas dapat disimpulkan bahwa ada tiga faktor yang dapat menimbulkan minat yaitu dorongan dari diri individu, dorongan sosial dan dorongan emosional. Timbulnya minat pada diri individu berasal dari individu itu sendiri, selanjutnya individu mengadakan interaksi dengan lingkungannya yang menimbulkan dorongan sosial dan dorongan emosional.

Menurut Charles yang dikutip oleh Slamet Widodo (1989:72) menjelaskan bahwa pada awalnya 
sebelum terlibat di dalam suatu aktivitas, siswa mempunyai perhatian terhadap adanya perhatian, menimbulkan keinginan untuk terlibat di dalam aktivitas. Minat kemudian mulai memberikan daya tarik yang ada atau ada pengalaman yang menyenangkan dengan hal-hal tersebut. Secara skematis proses terbentuknya minat dapat digambarkan sebagai berikut:

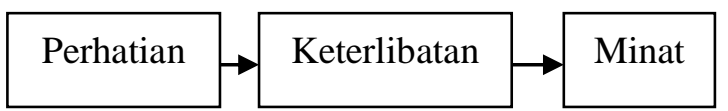

Gambar 1. Proses terbentuknya minat

Minat merupakan kecenderungan yang agak menetap pada diri individu, tidak terjadi begitu saja, tetapi melalui proses. Seseorang mempunyai minat dari pembawaanya, minat tersebut akan menetap dan berkembang pada dirinya untuk memperoleh dukungan dari lingkungannya yang berupa pengalaman. Pengalaman akan diperoleh dengan mengadakan interaksi dengan dunia luar, baik melalui latihan maupun belajar.

Faktor yang dapat menimbulkan minat belajar dalam hal ini adalah dorongan dari dalam individu, dorongan motif sosial dan dorongan emosional. Faktor yang menimbulkan minat, dalam hal ini minat untuk belajar ada tiga yaitu: dorongaan dari diri individu, dorongan sosial dan dorongan emosional. Timbulnya minat untuk belajar pada individu berasal dari dalam diri individu, kemudian individu mengadakan interaksi dengan lingkungan yang menimbulkan dorongan sosial dan dorongan emosional.

Sardiman, AM (2008:46) menyatakan bahwa halhal yang dapat mendorong atau menimbulkan minat belajar adalah sebagai berikut:

1. Adanya sifat ingin tahu dan ingin menyelidiki dunia yang labih luas.

2. Adanya sifat yang kreatif pada orang yang belajar dan keinginan untuk maju.

3. Adanya keinginan untuk mendapatkan simpati dari orang tua, guru dan teman-temannya.

4. Adanya keinginan untuk memperbaiki kegagalan yang lalu dengan usaha yang baru, baik dengan kooperasi maupun dengan kompetensi.

5. Adanya keinginan untuk mendapatkan rasa aman bila menguasai pelajaran.

6. Adanya ganjaran atau hukuman sebagai akhir dari belajar.

Berdasarkan pendapat di atas, maka dapat disimpulkan bahwa pengertian minat belajar adalah kecenderungan individu untuk memiliki rasa senang, dorongan melakukan aktivitas terhadap kegiatan belajar yang dilakukan melalui latihan-latihan ataupun pengalaman. Dengan demikian minat belajar pada diri siswa, maka kegiatan belajar akan dilakukan dengan penuh kesadaran, dilakukan dengan senang dan mempunyai dorongan untuk memperoleh hasil belajar yang optimal.

\section{B. Hasil Belajar}

Secara garis besarnya, karateristik Hasil Belajar dapat disebutkan sebagai berikut :

1. Hasil Belajar seseorang merupakan perubahan perilaku yang dapat diukur, dalam hal ini dengan menggunakan tes.

2. Hasil Belajar seseorang menunjuk pada individu, sebagai sebab, artinya individulah sebagai pelakunya.

3. Hasil Belajar dapat dievaluasi dengan menggunakan standard tertentu, baik berdasarkan norma kelompok ataupun norma yang tidak ditetapkan.

4. Hasil Belajar menunjukkan pula pada hasil kegiatan yang disengaja dan disadari yang dilakukan untuk mencapai suatu tujuan.

Dari uraian di atas dapat dinyatakan bahwa Hasil Belajar adalah hasil yang diperoleh terhadap jumlah mata pelajaran tertentu yang diukur dengan skor (nilai). Dengan demikian, Hasil Belajar merupakan suatu hasil dari usaha dan keinginan/aktifitas yang dilakukan individu dalam mencapai tujuan yang telah ditetapkan dan diukur berdasarkan standar tertentu. Hasil Belajar juga berarti suatu hasil usaha yang melahirkan suatu perubahan baru dan nyata yang merupakan indikator kemampuan siswa

\section{Hubungan antara Minat Belajar Dengan Hasil Belajar Siswa}

Minat sangat mempengaruhi proses dan hasil belajar siswa di sekolah. Jika seorang siswa kurang berminat untuk mempelajari sesuatu tidak dapat diharapkan bahwa dia akan berhasil dengan baik dalam mempelajari hal tersebut, sebaliknya kalau seorang mempelajari sesuatu dengan penuh minat, maka dapat diharapkan bahwa hasilnya akan lebih baik. Persoalan yang biasa timbul ialah bagaimana mengusahakan agar hal yang disajikan sebagai pengalaman belajar itu menarik para siswa, atau bagaimana caranya menentukan agar para siswa itu mengenai hal-hal yang memang menarik minat mereka. Minat dapat mempengaruhi persoalan mengenai pemilihan jurusan/pilihan program bidang studi pada lembaga-lembaga pendidikan formal. Sebaliknya pilihan program terhadap bidang studi itu dipilih yang benar-benar dengan minat para siswa, karena dengan demikian dapat diharapkan Hasil Belajar yang lebih baik. 


\section{METODE}

\section{A. Jenis Penelitian}

Jenis penelitian ini adalah penelitian deskriptif korelasional, yang berkaitan dengan pengumpulan data untuk memberikan gambaran atau penegasan suatu konsep atau gejala, guna menjawab pertanyaan yang akhirnya dapat mengambil suatu kesimpulan umum dari realita yang ada. Menurut Arikunto (2006:309) menyatakan bahwa penelitian deskriptif merupakan penelitian yang dimaksudkan untuk memgumpulkan informasi mengenai status suatu gejala yang ada, yaitu keadaan gejala menurut apa adanya pada saat penelitian dilakukan. Dengan demikian tujuan penelitian ini adalah untuk mengetahui hubungan minat belajar dengan hasil belajar mata pelajaran Solid Metal Arc Welding Siswa Kelas XI Jurusan Teknik Pengelasan SMK Negeri 1 Sumatera Barat.

\section{B. Waktu dan Tempat Penelitian}

Lokasi penelitian bertempat di SMK Negeri 1 Sumatera Barat beralamat Jln. M. Yunus, Lubuk Lintah Padang, sedangkan waktu penelitian direncanakan pada Maret hingga April 2019.

\section{Populasi dan Sampel}

\section{Populasi}

Menurut Arikunto (2006:18) "Populasi adalah keseluruhan objek penelitian apabila seseorang ingin meneliti semua elemen yang ada di dalam wilayah penelitian, maka penelitiannya merupakan penelitian populasi”.

Berdasarkan pendapat di atas, bahwa populasi adalah keseluruhan objek yang diteliti, maka populasi yang dinyatakan dalam penelitian ini adalah semua siswa kelas XI Jurusan Teknik Pengelasan yang mengikuti mata pelajaran Solid Metal Arc Welding yang berjumlah 48 orang.

Tabel 1. Jumlah Populasi Penelitian Siswa

\begin{tabular}{|l|c|r|}
\hline \multicolumn{1}{|c|}{ NO } & KELAS & JUMLAH SISWA \\
\hline 1. & Kelas XI TPa & 23 Siswa \\
\hline 2. & Kelas XI TPb & 25 Siswa \\
\hline \multicolumn{2}{|l|}{ Jumlah } & 48 Siswa \\
\hline
\end{tabular}

\section{Sampel}

Arikunto (2006:112) yang menyatakan bahwa: "Apabila subjeknya kurang dari 100 orang lebih baik diambil semua sehingga penelitiannya merupakan penelitian populasi selanjutnya jika jumlah subjeknya besar dapat diambil antara 10-15\% atau $20-25 \%$ atau lebih". Berdasarkan pendapat di atas, jumlah populasi dalam penelitian ini hanya berjumlah 48 orang sehingga diputuskan keseluruhan populasi dijadikan sampel dalam penelitian ini.

\section{Instrumen Penelitian}

1. Bentuk Instrumen

Data minat belajar siswa diambil dengan menggunakan angket. Pada penelitian ini digunakan angket yang disusun dengan pola skala likert, skala dalam bentuk kontinue yang terdiri dari empat kategori dan pernyataan amgket bersifat positif dan negatif.

\section{Penyusunan Instrumen}

Instrumen disusun melalui langkah-langkah sebagai berikut: (a) Membuat kisi-kisi kuesioner berdasarkan variabel yang diteliti, (b) Menyusun butir pernyataan sesuai dengan kisi-kisi yang telah dibuat, (c) Mendiskusikan dan berkonsultasi dengan dosen pembimbing untuk memperoleh kesahihan konstruk butir, dan (d) melaksanakan uji coba instrumen.

\section{E. Teknik Pengumpulan Data}

Pengumpulan data pada penelitian ini dilakukan dengan beberapa cara yaitu:

\section{Kuesioner}

Kuesioner diberikan kepada siswa kelas XI Jurusan Teknik Pengelasan yang mengikuti mata pelajaran Solid Metal Arc Welding yang berjumlah 48 orang.

\section{Hasil Belajar}

Hasil belajar dalam penelitian ini diambil dari nilai rata-rata ulangan harian yang dilakukan guru berdasarkan kompetensi dasar yang ada pada mata pelajaran Solid Metal Arc Welding.

\section{Dokumentasi}

Dokumentasi merupakan pengumpulan data yang diperoleh dari literature, atau arsip-arsip yang ada. Data yang diperoleh berupa jumlah siswa kelas XI Teknik Pengelasan dan proses pelaksanaan penelitian.

\section{F. Teknik Analisis Data}

Teknik yang digunakan untuk menerangkan minat belajar dan hasil belajar siswa peneliti menggunakan teknik analisis sebagai berikut:

1. Deskripsi Data penelitian

Analisis deskriptif ini dimaksudkan untuk menggambarkan masing-masing variabel secara mandiri yaitu minat belajar (X) dan hasil belajar (Y). Deskripsi data yang diungkapkan adalah skor tertinggi, skor terendah, rata-rata skor (mean), skor tengah (median), skor yang banyak muncul (mode), 
dan standar deviasi. Perhitungan deskripsi data tersebut menggunakan bantuan komputer program SPSS Versi 22.00 (Statical Package for Social Sciences).

Untuk mendapatkan tingkat pencapaian responden pada masing-masing variabel berpedoman pada Riduwan dan Akdon (2006:148) dengan rumus sebagai berikut:

Tingkat pencapaian $=\frac{\text { Rata }- \text { rata }}{\text { Skor IdealMak. }} \times 100 \%$

Pengkategorian nilai pencapaian responden digunakan klasifikasi Sujana (1989:118) sebagai berikut:

$$
\begin{aligned}
& 90-99 \%=\text { Sangat Baik } \\
& 80-89 \%=\text { Baik } \\
& 70-79 \%=\text { Cukup } \\
& 60-69 \%=\text { Kurang } \\
& 0-59 \%=\text { Gagal }
\end{aligned}
$$

\section{Uji Persyaratan Analisis}

Agar data penelitian yang diperoleh dapat dipakai dengan menggunakan analisis statiska, pada uji hipotesis penelitian yang menerapakan rumus kolerasi product momen, maka terlebih dahulu memenuhi persyaratan analisis. Uji persayaratan analisis yang dilakukan adalah untuk mengetahui apakah data penelitian sudah mempunyai sebaran normal serta untuk mengetahui apakah data veriabel bebas $(\mathrm{X})$ linier terhadap data veriabel terikat $(\mathrm{Y})$. Untuk itu dilakukan uji normalitas dan uji linieritas.

\section{a. Uji Normalitas}

Uji normalitas untuk mengetahui apakah sebaran berasal dari populasi berdistribusi normal atau tidak. Pengujian normalitas dilakukan terhadap masingmasing variabel $\mathrm{X}$ dan Variabel $\mathrm{Y}$. Pengujian normalitas kedua variabel ini dilakukan dengan menggunakan uji Lilliefors yang telah diprogram dalam Program Paket Statistik Baku SPSS Versi 22.00. Taraf signifikansi yang digunakan sebagai dasar menolak atau menerima keputusan normal atau tidaknya suatu distribusi data adalah $\alpha=0,05$. Menurut Santoso (2000:102) pedoman dalam pengambilan keputusan kedua alat uji ini adalah jika nilai signifikansi atau nilai probalitas $<0,05$ maka distribusi tidak normal sebaliknya jika nilai probalitas $>0,05$ maka distribusi adalah normal.

b. Uji linieritas

Pengujian linearitas bertujuan untuk mengetahui hubungan antara variabel $\mathrm{X}$ dengan variabel $\mathrm{Y}$ linear atau tidak. Untuk uji itu digunakan uji Anova (Analisis of Varians) dengan rumus:

$$
F_{\text {hitung }}=\frac{\text { RJK }_{\mathrm{TC}}}{\mathrm{RJK}_{\mathrm{E}}} \quad \text { (Riduwan, 2005) }
$$

Keterangan:
$\mathrm{F}=$ nilai $\mathrm{F}$

RJK $_{\mathrm{TC}}=$ Rata-rata jumlah kuadrat tuna cocok

RJK $_{\mathrm{E}}=$ Rata-rata jumlah kuadrat kesalahan (error)

Menentukan variabel bebas mempunyai hubungan linear berdasarkan:

- Jika nilai signifikansi (deviation from linierity) < 0,05 (taraf kepercayaan 95\%), maka sebaran data variabel bebas tidak membentuk garis linear terhadap variabel terikat.

- Jika nilai signifikansi (deviation from linierity) > 0,05 (taraf kepercayaan 95\%), maka sebaran data variabel bebas membentuk garis linear terhadap variabel terikat.

\section{Uji Hipotesis Penelitian}

Pengujian hipotesis penelitian yaitu terdapat hubungan yang positif dan berarti antara minat belajar dengan hasil belajar digunakan rumus kolerasi product moment seperti yang dikemukakan Arikunto (2006: 72), sebagai berikut:

$$
\mathrm{r} x \mathrm{y}=\frac{(\mathrm{N} \cdot \Sigma \mathrm{XY})-(\Sigma \mathrm{X}) \cdot(\Sigma \mathrm{Y})}{\sqrt{\left.\left[\mathrm{N}^{2} \Sigma \mathrm{X}^{2}\right)-(\Sigma \mathrm{X})^{2}\right]\left[\left(\mathrm{N} \cdot \Sigma \mathrm{Y}^{2}\right)-(\Sigma \mathrm{Y})^{2}\right]}}
$$

Kemudian untuk mengetahui keberartian hubungan minat belajar dengan hasil belajar, dilakukan dengan uji-t seperti yang dikemukakan Sudjana (1992 : 48), sebagai berikut:

$$
\mathrm{t}=\frac{r x y \sqrt{\mathrm{N}-2}}{\sqrt{1-r x y^{2}}}
$$

besaran $\mathrm{t}_{\text {hitung }}$ yang diperoleh dikonsultasikan terhadap $\mathrm{t}_{\text {tabel }}$ pada taraf signifikasi $5 \%$ dengan $\mathrm{dk}=$ $\mathrm{N}-2$. Bila $\mathrm{t}_{\text {hitung }}>\mathrm{t}_{\text {tabel }} 5 \%$, maka disimpulkan bahwa besaran korelasi mempunyai keberartian antara minat belajar dengan hasil belajar. Analisa data untu pengujian hipotesis ini dibantu dengan menggunakan Program SPSS For Windows Versi 22.00 .

\section{HASIL DAN PEMBAHASAN}

\section{A. Hasil Penelitian}

Hipotesis yang diajukan adalah "Terdapat hubungan positif antara minat belajar dengan hasil belajar siswa dalam bidang studi SMAW siswa Kelas XI Teknik Pengelasan SMK Negeri 1 Sumatera Barat Tahun pembelajaran 2018/2019.

\section{Koefeisien korelasi}

Koefesien korelasi menggunakan koefesien korelasi pearson (r) antara minat belajar dengan hasil belajar SMAW. Analisis dikukan dengan menggunakan SPSS versi 22.00. Berikut adalah hasil analisis koefesien korelasi X dengan Y. 
Tabel 2. Koefisien Korelasi X dengan Y

\begin{tabular}{|l|l|r|r|}
\hline \multicolumn{2}{|c|}{} & $\begin{array}{l}\text { Minat_ } \\
\text { Belajar }\end{array}$ & $\begin{array}{c}\text { Hasil_ } \\
\text { Belajar }\end{array}$ \\
\hline \multirow{7}{*}{ Minat_Belajar } & $\begin{array}{l}\text { Pearson } \\
\text { Correlation }\end{array}$ & 1 &, 298 \\
\cline { 2 - 4 } & Sig. (2-tailed) & &, 103 \\
\cline { 2 - 4 } & N & 48 & 48 \\
\hline Hasil_Belajar & $\begin{array}{l}\text { Pearson } \\
\text { Correlation }\end{array}$ &, 298 & 1 \\
\cline { 2 - 4 } & Sig. (2-tailed) &, 103 & \\
\cline { 2 - 4 } & $\mathrm{N}$ & 48 & 48 \\
\hline
\end{tabular}

Dari tabel 2 terlihat nilai $r$ hitung $=0,298$. Nilai $r$ tabel adalah $=0,284$. Bila dibandingkan dengan nilai $r$ hitung $>r$ tabel. Maka dapat disimpulkan bahwa koefesien korelasi yang didapatkan bernilai positif maka variabel minat belajar terhadap variabel hasil belajar SMAW berkorelasi positif artinya variabel minat belajar yang naik/turun maka variabel hasil belajar SMAW juga naik/turun.

\section{Koefeien Determinasi}

Besaran koefeien determinasi dalam penelitian ini didapatkan dari nilai $r$ square. Berikut hasil analisis besaran nilai koefisien penentu antara variabel minat belajar terhadap hasil belajar SMAW.

\section{Tabel 3. Analisis Koefisien Determinasi} Model Summary

\begin{tabular}{|l|c|r|r|c|}
\hline & & $\begin{array}{c}\text { R } \\
\text { Model }\end{array}$ & $\mathrm{R}$ & Adjusted \\
Square & $\begin{array}{c}\text { Std. Error } \\
\text { of the } \\
\text { Estimate }\end{array}$ \\
\hline 1 &, $298^{\mathrm{a}}$ &, 089 &, 036 & 11,19596 \\
\hline
\end{tabular}

a. Predictors: (Constant), Minat_Belajar

Berdasarkan hasil analisis diperoleh pula nilai koefisien determinasi sebesar 0,089. Dari nilai koefisien determinasi tersebut dapat dijelaskan bahwa besarnya sumbangan minat belajar terhadap hasil belajar SMAW adalah 8,9\% dan selebihnya yaitu $91,1 \%$ dipengaruhi faktor lain diluar minat belajar yang tidak dikaji dalam penelitian ini.

\section{Uji Kebeartian Hubungan}

Dalam rangka menguji hipotesis penelitian ini digunakan analisis regresi linier sederhana karena data yang diperoleh telah menuhi uji prasyarat analisis yaitu data dari kedua variabel berdistribusi normal dan berbentuk linier. Adapun hipotesis yang dirumuskan adalah:
$\mathrm{H}_{0}$ : Terdapat hubungan positif yang signifikan antara Minat Belajar dengan Hasil Belajar SMAW
$\mathrm{H}_{1}$ : Tidak Terdapat hubungan positif yang signifikan antara Minat Belajar dengan Hasil Belajar SMAW

Interpretasi :

Bila $t_{\text {hitung }}>t_{\text {tabel }}$ pada taraf signifikan $>0,05$ maka Ho ditolak

Bila $\mathrm{t}_{\text {hitung }}<\mathrm{t}_{\text {tabel }}$ pada taraf signifikan $<0,05$ maka Ho diterima

Berdasarkan perhitungan komputasi SPSS versi 22.00 diperoleh persamaan regresi sebagai berikut:

Tabel 4. Hasil Regresi Linear Sederhana X ke Y Coefficients $^{\text {a }}$

\begin{tabular}{|l|l|r|r|c|c|c|}
\hline \multirow{2}{*}{} & \multicolumn{2}{|c|}{$\begin{array}{c}\text { Unstandardized } \\
\text { Coefficients }\end{array}$} & $\begin{array}{c}\text { Standardized } \\
\text { Coefficients }\end{array}$ & & \\
\cline { 2 - 6 } & \multicolumn{1}{|c|}{ B } & $\begin{array}{c}\text { Std. } \\
\text { Error }\end{array}$ & Beta & t & \multirow{2}{*}{ Sig. } \\
\hline \multirow{2}{*}{1} & Model Constant) & 39,552 & 19,959 & & 1,982 &, 024 \\
\cline { 2 - 6 } & Minat_Belajar &, 430 &, 258 &, 238 & 1,664 &, 013 \\
\hline
\end{tabular}

a. Dependent Variable: Hasil_Belajar

Berdasarkan hasil analisis, nilai signifikan yang didapat kan adalah 0,013. Dapat disimpulkan bahwa hipotesis dapat diterima. Hasil ini menunjukkan persamaan regresi dari Minat Belajar $(\mathrm{X})$ terhadap Hasil Belajar SMAW (Y) yaitu : $\hat{Y}=39,552+$ $0,430 X$. Keberartian persamaan regresi yang diperoleh tersebut dapat diuji dengan analisis varians untuk regresi atau uji $\mathrm{F}$ yang hasilnya seperti tersaji pada tabel berikut:

Tabel 5. Hasil Analisis Varian untuk Regresi X ke $\mathrm{Y}$

ANOVA ${ }^{\mathrm{a}}$

\begin{tabular}{|ll|r|r|c|c|c|}
\hline \multicolumn{2}{|c|}{ Model } & $\begin{array}{c}\text { Sum of } \\
\text { Squares }\end{array}$ & df & $\begin{array}{c}\text { Mean } \\
\text { Square }\end{array}$ & F & Sig. \\
\hline 1 & Regression & 346,902 & 1 & 346,902 & 2,767 &, $013^{\mathrm{a}}$ \\
& Residual & 5766,078 & 46 & 125,350 & & \\
& Total & 6112,979 & 47 & & & \\
\hline
\end{tabular}

a. Dependent Variable: Hasil_Belajar

b. Predictors: (Constant), Minat_Belajar

Berdasarkan hasil analisis varians untuk regresi pada tabel 5 di atas diperoleh nilai $F_{\text {hitung }}=2,767$ dengan signifikansi $0,000<0,05$. Jadi dapat diputuskan bahwa hipotesis penelitian $\left(\mathrm{H}_{0}\right)$ yang menyatakan "Adanya hubungan positif antara Minat Belajar terhadap Hasil Belajar SMAW", maka analisis diterima.

\section{B. Pembahasan}

Berdasarkan hasil analisis ini didapatkan tingkat minat belajar siswa dalam pembelajaran SMAW tergolong kurang. Hasil ini cukup memperihatinkan. Untuk mengetahui lebih dalam peneliti melakukan analisis pada masing-masing indikator minat belajar siswa. Hal ini dilakukan untuk mengetahui pointpoint yang menjadi rendahnya minat belajar siswa. Beriikut adalah rangkuan hasil analisis per indikator 
minat bejalar siswa pada mata pelajaran SMAW. Dari hasil analisis pada masing-masing indikator didapatkan rata-rata capaian responden berada pada kategori kurang. Dari ketujuh indikator yang digunakan didapatkan indikator keinginan mencapatkan sesuatu memperoleh nilai tertinggi yaitu $66 \%$. Sedangkan nilai terendah berada pada indikator sikap pisitif terhadap pembelajaran yanitu $60 \%$.

Pada variabel hasil belajar SMAW diperoleh ratarata tingkat capaian responden variabel hasil belajar sebesar 72,64\%, dan masuk ke dalam kategori cukup. Analisis data hasil belajar SMAW mencerminkan nilai siswa hanya berada sedikit diatas nilai batas KKM yang ditetapkan dalam pembelajaran SMAW. Hal ini menimbulkan asumsi rendahnya minat dimungkinkan disebabkan oleh faktor-faktor lain seperti kompetensi guru, fasilitas belajar dan metode pembalajaran yang menjadikan minat belajar rendah dan hasil belajarpun rendah.

Hasil analisis hipotesis dalam penelitian ini didapatkan nilai $r$ hitung $=0,298$. Nilai $r$ tabel adalah $=0,284$. Bila dibandingkan dengan nilai $r$ hitung $>r$ tabel. Maka dapat disimpulkan bahwa koefesien korelasi yang didapatkan bernilai positif maka variabel minat belajar terhadap variabel hasil belajar SMAW berkorelasi positif artinya variabel minat belajar yang naik/turun maka variabel hasil belajar SMAW juga naik/turun.

Untuk analisis koefisien determinasi diperoleh nilai sebesar 0,089. Dari nilai koefisien determinasi tersebut dapat dijelaskan bahwa besarnya sumbangan minat belajar terhadap hasil belajar SMAW adalah $8,9 \%$ dan selebihnya yaitu $91,1 \%$ dipengaruhi faktor lain diluar minat belajar yang tidak dikaji dalam penelitian ini.

Uji keberartian hubungan didapatkan nilai signifikan adalah 0,013. Dapat disimpulkan bahwa hipotesis dapat diterima. Hasil ini menunjukkan persamaan regresi dari Minat Belajar (X) terhadap Hasil Belajar SMAW (Y) yaitu : $\hat{Y}=39,552+$ 0,430X. Keberartian persamaan regresi yang diperoleh tersebut dapat diuji dengan analisis varians untuk regresi atau uji F. Berdasarkan hasil analisis varians untuk regresi diperoleh nilai Fhitung $=2,767$ dengan signifikansi $0,000<0,05$. Jadi dapat diputuskan bahwa hipotesis penelitian (H0) yang menyatakan "Adanya hubungan positif antara Minat Belajar terhadap Hasil Belajar SMAW", maka analisis diterima

Hasil penelitian mengungkapkan adanya sumbangan hubungan positif antara minat belajar dengan hasil belajar siswa dalam bidang studi SMAW siswa Kelas XI Teknik Pengelasan SMK Negeri 1 Sumatera Barat Tahun pembelajaran 2018/2019. Hal ini memberikan arti semakin tinggi minat belajar maka hasil belajar SMAW semakin tinggi pula hasil belajarnya. Minat merupakan salah satu indikator yang berperan dalam proses belajar siswa. Minat yang tinggi akan memberikan kontribusi positif bagi kelancaran proses belajar mengajar. Dengan demikian seorang guru harus dapat meningkatkan minat belajar siswa agar siswa mampu menguasai materi pelajaran yang diberikan. Minat sangat mempengaruhi proses dan hasil belajar siswa di sekolah. Jika seorang siswa kurang berminat untuk mempelajari sesuatu tidak dapat diharapkan bahwa dia akan berhasil dengan baik dalam mempelajari hal tersebut, sebaliknya kalau seorang mempelajari sesuatu dengan penuh minat, maka dapat diharapkan bahwa hasilnya akan lebih baik. Persoalan yang biasa timbul ialah bagaimana mengusahakan agar hal yang disajikan sebagai pengalaman belajar itu menarik para siswa, atau bagaimana caranya menentukan agar para siswa itu mengenai hal-hal yang memang menarik minat mereka.

\section{KESIMPULAN}

Kesimpulan dalam penelitian ini yaitu, minat belajar responden sebesar 62,11 dan masuk dalam kategori kurang dan prestasi belajar sebesar 72,64\%, dan masuk ke dalam kategori cukup juga terdapat pengaruh yang positif dan berarti antara minat belajar dengan hasil belajar bidang studi SMAW siswa kelas XI jurusan teknik pengelasan SMK Negeri 1 Sumatera Barat tahun pembelajaran 20182019.

\section{DAfTAR PUSTAKa}

[1] Arikunto. 2006. Prosedur Penelitian Suatu Pendekatan Praktek. Jakarta: Rineka Cipta

[2] Pujadi, Arko. 2007. "Faktor-Faktor yang Mempengaruhi Motivasi Belajar Mahasiswa: Studi Kasus pada Fakultas Ekonomi Bunda Mulia”. Busines \& management Journal Bunda Mulia, 3 (2): 41-51, September 2007.

[3] Riduwan dan Akdon. 2006. Rumus dan Data dalam Aplikasi Statistika. Cetakan I. Bandung : Alfabeta

[4] Riduwan. 2005. Skala Pengukuran VariabelVariabel Penelitian. Bandung: Alfabeta.

[5] Santoso. 2000. Statistika Dasar untuk Penelitian. Surakarta: FKIP UNS Press.

[6] Sardiman, AM. 2008. Psikologi Pembelajaran dan Pengajaran. Bandung: Pustaka Bani Quraisy.

[7] Slamet Widodo. 1989. Belajar Dan Factor-Faktor Yang Mempengaruhinya. Jakarta: Bina Bangsa

[8] Slameto. 2003. Psikologi Pendidikan Dengan Pendekatan Baru. Bandung:PT Remaja Rosdakarya. 
[9] Suharsimi, Arikunto. 1983. Prosedur Penelitian. Jakarta: Bina Aksara.

[10] Walgito, Bimo. 1981. Psikologi Umum. Yogyakarta: Penka Fakultas Psikologi UGM. 